\title{
INHALT CONTENTS
}

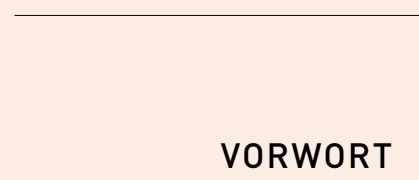

Christoph Badelt, Rektor

GESCHICHTE

FÜLLE UND HÜLLE

Zur Institutions- und Baugeschichte der Wirtschaftsuniversität Wien 1873-1982

Markus Kristan

\section{ZWEI WETTBEWERBE FÜR EINEN CAMPUS}

Franziska Leeb

STARKE IDENTITÄTEN POLARISIEREN

Dietmar Eberle im Gespräch mit Edith Schlocker

EINE LEBENDIGE STADT

Wolf D. Prix im Gespräch mit Matthias Boeckl

\section{MASTERPLAN}

INTEGRAL UND DIFFUSIONSOFFEN

Der Masterplan von BUSarchitektur

Isabella Marboe

RAUM UND KOMMUNIKATION

Reflexionen zur Campus-Philosophie

Gerlinde Mautner

\section{BAUTEN - NUTZER - THEMEN}

EIN NEUES LEBENSGEFÜHL

Das Library and Learning Center von

Zaha Hadid Architects

Matthias Boeckl

WAS IST EIN LEARNING CENTER? WIE FUNKTIONIERT ES?

Statements

Cordula Rau
PREFACE

Christoph Badelt, Rector

\section{HISTORY}

8 NEVER ENOUGH AND NOTHING TO SPARE

On the Institutional and Architectural History of Vienna

University of Economics and Business 1873-1982

Markus Kristan

14 TWO COMPETITIONS FOR ONE CAMPUS

Franziska Leeb

22 STRONG IDENTITIES POLARIZE

Dietmar Eberle in conversation with Edith Schlocker

25 A LIVELY CITY

Wolf D. Prix in conversation with Matthias Boeckl

\section{MASTER PLAN}

28 INTEGRAL AND PERMEABLE

The Master Plan by BUSarchitektur

Isabella Marboe

38 SPACE AND COMMUNICATION

Reflections on the Campus Philosophy

Gerlinde Mautner

\section{BUILDINGS · USER · THEMES}

42 A NEW QUALITY OF LIFE

The Library and Learning Center by

Zaha Hadid Architects

Matthias Boeckl

56 WHAT IS A LEARNING CENTER?

HOW DOES IT FUNCTION?

Statements

Cordula Rau 
GEBAUTE LERNLANDSCHAFT

Das Teaching Center von BUSarchitektur

Isabella Marboe

INTEGRATION ARCHITEKTONISCHER UND STRUKTURELLER KOMPLEXITÄT

Konstruktions-Highlights am WU Campus

Andrei Gheorghe

SCHICHTEN UND FÜLLUNGEN

Das Departmentgebäude und Student Center von Atelier Hitoshi Abe

Matthias Boeck

STUDIEREN AM WU CAMPUS

Statements

Robert Temel

HEITERKEIT ALS PROGRAMM

Das Department- und Administrationsgebäude von CRAB studio

Cordula Rau

DER GRÜNE CAMPUS

Energie-Design-Konzepte

Malgorzata Sommer-Nawara, Bernhard Sommer

EIN SPIEL MIT PARALLELOGRAMMEN

Departmentgebäude von Estudio Carme Pinós Ulrich Tragatschnig

DER NEUE CAMPUS AUS SICHT DER LEHRENDEN

Statements

Ulrich Tragatschnig

NICHT-KARTESIANISCHE GEOMETRIEN

Eduardo Arroyo über die Executive Academy im Gespräch mit Gudrun Hausegger

SCHNITTSTELLEN - ARBEITS-BEZIEHUNGEN ZUR GEBAUTEN CAMPUS-UMWELT

Statements

Daniel Grünkranz

SICH NICHT FÜRCHTEN

Über die große Aufgabe, eine Universität auf die grüne Wiese zu bauen

Maximilian Pammer, Christoph Sommer

ZAHLEN · DATEN · FAKTEN KURZBIOGRAFIEN
UILT EDUCATIONAL LANDSCAPE The Teaching Center by BUSarchitektur Isabella Marboe

74 THE INTEGRATION OF ARCHITECTURAL AND STRUCTURAL COMPLEXITY Construction Highlights on the WU Campus Andrei Gheorghe LAYERS AND FILLING

The Departments and Student Center by Atelier Hitoshi Abe Matthias Boeckl

92 STUDENTS ON THE WU CAMPUS Statements

Robert Temel

98 JOLLY GOOD FUN

The Department and Administration Building by CRAB studio Cordula Rau

THE GREEN CAMPUS

Energy Design Concepts

Malgorzata Sommer-Nawara, Bernhard Sommer

118

AN INTERPLAY OF PARALLELOGRAMS Department Building by Estudio Carme Pinós Ulrich Tragatschnig

128 THE NEW CAMPUS FROM THE VIEWPOINT OF THE TEACHERS Statements

Ulrich Tragatschnig

134 NON-CARTESIAN GEOMETRIES

Eduardo Arroyo on the Executive Academy

in conversation with Gudrun Hausegger

INTERFACES - WORK RELATIONSHIPS IN THE ARCHITECTURE OF THE CAMPUS

Statements

Daniel Grünkranz

152 TO NOT BE AFRAID

About the challenge of constructing a university from scratch

Maximilian Pammer, Christoph Sommer

156 FACTS AND FIGURES

157 SHORT BIOGRAPHIES 